\title{
Designing an Undergraduate Food Processing LABORATORY FOR THE UNIVERSITY OF WATERLOO
}

\author{
Yung P. Lai, Kyung E. K. Sun, Hiroki Takamura, Christine Moresoli, and Marc Aucoin \\ Department of Chemical Engineering, University of Waterloo \\ cmoresoli@uwaterloo.ca, marc.aucoin@uwaterloo.ca
}

\begin{abstract}
Food processing is one of the largest industries in the world, making it an attractive field for chemical engineering students to pursue. Currently, there is no food processing laboratory at the University of Waterloo. Consequently, students do not have an opportunity to link fundamental chemical and biological engineering concepts germane to the food processing industry to tangible applications. The solution is to design a versatile undergraduate food processing laboratory to enhance the engineering undergraduate experience. The laboratory would have three unit operations ubiquitous to the food industry. The three selected unit operations were spray drying, micro-encapsulation, and extrusion. Suppliers and/or providers of processing equipment, raw ingredients, and pest control services were identified with the consideration of health and safety recommendations. The food processing laboratory layout was created with consideration of minimizing workplace hazards and the risk of food contamination. The cost of running the laboratory for the first year along with equipment/materials procurement was estimated to be around $\$ 1$ million $C A D$ in an existing room at the university. By providing a food processing laboratory, chemical engineering students would be supplied a contained learning environment along with the incentive to consume their manufactured products.
\end{abstract}

Keywords: food processing, undergraduate, laboratory design

\section{INTRODUCTION}

The overall goal of the project was to design a versatile undergraduate food processing laboratory to enhance the undergraduate experience in one of the largest industries in the world. Chemical engineering students that have strong interest in the food processing industrial sector do not currently have a learning environment to implement their knowledge at the university. The project was constrained by cost, safety requirements, laboratory space availability, and the characteristics of the three selected unit operations. Its success was measured by the identification of suppliers for the selected unit operations, the development of design specifications and layout of the available space, and the cost of the proposed equipment and space modifications. The results of the project would assist with equipment procurement and implementation of a food processing laboratory at the university.

\section{METHODOLOGY}

The project was divided in two parts. The first part was equipment selection for the three selected unit operations:

(1) Spray drying, representing a common unit operation in the food industry, where atomized liquid droplets are dried with hot air to produce powder. It is a preferred drying unit operation in industry, due to its low manufacturing cost, good product quality attributes and continuous process operation.

(2) Micro-encapsulation, a process in which a coating is applied on a material to protect this material against harsh environment or processing conditions.

(3) Extrusion, where raw ingredients are transformed in a wide range of shapes after their mixing, heating and shaping through a die.

Potential target food products were specified for each unit operation - egg powder for spray drying, probiotics for micro-encapsulation, and pasta for extrusion. Based on a decision-making matrix, the most suitable equipment for each unit operations was determined.

In the second part of the project, the equipment layout and laboratory facilities were designed based on general laboratory design specifications, ergonomics, user and food safety considerations for a maximum room capacity of nine people in the laboratory at a time. The most suitable structural material (i.e. floors and wall material) and laboratory environmental conditions (i.e. temperature, air filtration) were also determined. Finally, the cost for the implementation of the three selected unit operations was estimated. 


\section{RESULTS AND DISCUSSION}

\subsection{Equipment Selection}

Equipment selection was based on six criteria: versatility, cost, productivity (for extruder and spray dryer only), energy consumption, waste production, and sterility (for micro-encapsulator only). For each of the criterion, each equipment was rated on a scale of 1 to 20 - 20 being the best rating for the equipment and 1 being the worst. The ratings were inputted into a decision-making matrix and summed up for each equipment. The equipment with the greatest total score for each unit operation were selected. They were the following: GEA Niro Mobile Minor for the spray dryer, Nisco Var D for the microencapsulator, and Zhouheng ZH2000-100 for the extruder.

\subsection{Safety}

Safety considerations considered include:

- Personal protective equipment, such as goggles, hairnet, lab coats and ear plugs, need to be prepared for students working in the laboratory

- Eye wash stations located such that they can be reached within 5 seconds $[2,3]$

- Emergency showers should be within the range of $25 \mathrm{ft}$ from any point in the laboratory $[2,3]$

- Regular cleaning of spray dryer is required to prevent dust explosion

- Countertop should be at least $3 \mathrm{ft}$ high

Food processing facility or factory requirements and recommendations based on 11 AMI (American Meat Institute) Principles of Sanitary Facility Design [1] and cleanroom specifications were also considered when designing the laboratory. The structural materials and the environmental conditions are summarized in Table 1 and Table 2 respectively. This was to ensure maximum cleanliness for food consumption in the laboratory.

Table 1: Structural materials for food processing laboratory [1]

\begin{tabular}{|c|c|}
\hline & Materials \\
\hline Floor & Dairy tile \\
\hline Wall & Tile \\
\hline Cabinetry/ Countertops & Stainless steel \\
\hline Water (hot/cold) pipe & PVC \\
\hline Distilled water & Polyethylene or Teflon \\
\hline Ceiling* & $\begin{array}{c}\text { Plastic-finished acoustical } \\
\text { ceiling tiles }\end{array}$ \\
\hline
\end{tabular}

* Clean room specification $[2,3]$
Table 2: Food processing laboratory environmental conditions [1]

\begin{tabular}{|c|c|}
\hline & Requirements \\
\hline Temperature & $10^{\circ} \mathrm{C}$ \\
\hline Relative Humidity* & $45 \% \pm 10 \%$ \\
\hline Pressure difference* & 0.05 inch $\mathrm{H}_{2} \mathrm{O}$ \\
\hline Air filter & $\mathrm{HEPA}$ filter \\
\hline Air Exchange Rate* & $0.46 \mathrm{~m} / \mathrm{s}$ \\
\hline
\end{tabular}

* Clean room specification $[2,3]$

Accordingly, the following considerations were established when developing the laboratory layout:

- Isolation of each station/unit to minimize crosscontamination

- Continuous process flow of work stations to optimize productivity

- Minimization of cost regarding construction and renovation

- $\quad$ Safe and sterile environment

\subsection{Laboratory Layout Design}

A decision-making matrix was developed for the selection of the best laboratory layout. The criteria were (1) crossflow traffic analysis, (2) area efficiency and (3) traffic load in each station of the laboratory. The best laboratory layout, shown in Fig. 1, had minimal crossflow traffic analysis (20 total crossing points for flows through each processing area), best area efficiency (86\%) and lowest traffic load in each processing area $(\leq 2$ people going through a point in each processing area and mobility of each person was higher in each processing area).

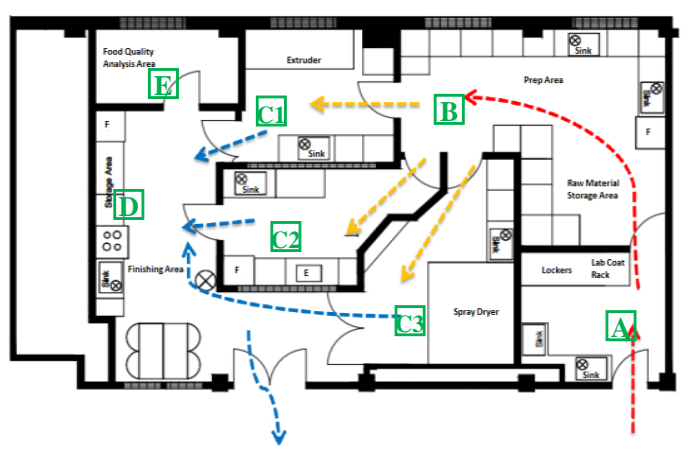

Fig. 1. Final food processing laboratory layout. Arrows represent the flow of personnel and materials into and out of the lab. 'A, B, C1, C2, C3, D, E' represents the washing area, preparation and raw materials storage area, extruder processing area, micro-encapsulation processing area, spray dryer processing area, finishing area for cooking of food products and packaging, and food quality analysis area respectively. 


\subsection{Cost Estimation}

The cost for implementing the laboratory for the first year was computed shown in Table 3.

Table 3: Cost breakdown

\begin{tabular}{|c|c|c|}
\hline Category & Sub-category & Cost (\$CAD) \\
\hline \multirow{3}{*}{ Fixed cost } & $\begin{array}{l}\text { Spray dryer, micro- } \\
\text { encapsulator, and } \\
\text { twin screw extruder }\end{array}$ & $321,163.5$ \\
\hline & $\begin{array}{l}\text { Other auxiliary } \\
\text { equipment (balances, } \\
\text { trays, stove, } \\
\text { ultrasonic bath, etc.) }\end{array}$ & $13,511.25$ \\
\hline & $\begin{array}{l}\text { Renovation } \\
\text { (assuming } \sim \$ 290 / \mathrm{ft}^{2} \text { ) }\end{array}$ & $360,650.00$ \\
\hline \multirow{9}{*}{$\begin{array}{l}\text { Direct } \\
\text { manufacturing } \\
\text { cost }\end{array}$} & Raw materials & $1,073.44$ \\
\hline & $\begin{array}{l}\text { Utilities (operating } \\
\text { the three main } \\
\text { equipment } 20 \mathrm{hrs} / \mathrm{yr} \text { ) }\end{array}$ & 29.40 \\
\hline & Maintenance & $41,719.48$ \\
\hline & Operating labour & $1,320.00$ \\
\hline & $\begin{array}{l}\text { Supervisory costs and } \\
\text { clerical costs }(20 \% \text { of } \\
\text { operating labour }\end{array}$ & 264.00 \\
\hline & $\begin{array}{l}\text { Lab charges ( } 15 \% \text { of } \\
\text { operating labour) }\end{array}$ & 198.00 \\
\hline & Pest control & $1,800.00$ \\
\hline & Hair nets & 92.6 \\
\hline & $\begin{array}{l}\text { Operating supplies } \\
\text { (15\% of maintenance } \\
\text { costs) }\end{array}$ & $6,257.92$ \\
\hline \multirow[t]{2}{*}{$\begin{array}{l}\text { Indirect } \\
\text { manufacturing } \\
\text { cost }\end{array}$} & $\begin{array}{l}\text { Overhead }(60 \% \text { of } \\
\text { operating labour }+ \\
\text { supervisory }+ \\
\text { maintenance cost) }\end{array}$ & $25,982.091$ \\
\hline & $\begin{array}{l}\text { Insurance } \\
(1.5 \% \text { of fixed cost })\end{array}$ & $10,429.87$ \\
\hline $\begin{array}{l}\text { General } \\
\text { expenses }\end{array}$ & $\begin{array}{l}\text { Depreciation } \\
(10 \% \text { of fixed cost })\end{array}$ & $69,532.48$ \\
\hline $\begin{array}{l}\text { Total expenses } \\
\text { for first year }\end{array}$ & $\begin{array}{l}\text { Total }+18 \% \\
\text { contingency }\end{array}$ & $1,007,748.36$ \\
\hline
\end{tabular}

Note: Fridges and autoclaves were not included as auxiliary equipment

\section{CONCLUSION}

Safety considerations guided the laboratory layout design. The major safety consideration incorporated into the layout was dividing the laboratory into five stations to minimize cross-contamination among the processing areas. The greatest cost for the proposed laboratory came from the procurement of the three selected equipment and the renovation costs. For $\sim \$ 1$ million CAD in the first year, a safe, accommodative laboratory with three unit operations, spray drying, extrusion and microencapsulation, could be installed in an available space at the university.

\section{Acknowledgements}

Our sincere thanks also goes to Professor D. Leven at the University of Toronto for the opportunity to visit his laboratory to gain information on the extrusion and the spray drying equipment, and Dr. $\mathrm{X}$. Hu, for the opportunity to tour the food processing facility at the Guelph Food Technology Center. We would also like to thank Tom Dean at the University of Waterloo for his guidance on our laboratory layouts.

\section{References}

[1] Michael M. Cramer, Food Plant Sanitation: Design, Maintenance, and Good Manufacturing Practices. Boca Raton, FL: Taylor and Francis Group LLC, 2006, 283 pp. \{ISBN: 978-0849-34197-7\}

[2] Fernand Dahan, Laboratories: A Guide to Master Planning, Programming, Procurement, and Design. New York: Norton \& Company Ltd., 2000, 298 pp. \{ISBN: 978-039373058-6\}

[3] Louis J. Diberardinis, Gari T. Gatwood, Janet S. Baum, Edward Groden, Melvin W. First and Anand K. Seth, Guidelines for Laboratory Design: Health and Safety Considerations. Toronto,ON: John Wiley \& Sons Inc., 1987 (2nd ed.), 285 pp. \{ISBN: 978-0471-55463-9 \} 